\title{
A highly specific PCR assay for detecting the fish ectoparasite Amyloodinium ocellatum
}

\author{
Michael G. Levy ${ }^{1, *}$, Matthew F. Poore ${ }^{1}$, Angelo Colorni ${ }^{2}$, Edward J. Noga ${ }^{1}$, \\ Mark W. Vandersea ${ }^{3}$, R. Wayne Litaker ${ }^{3}$ \\ ${ }^{1}$ College of Veterinary Medicine, North Carolina State University, 4700 Hillsborough Street, Raleigh, \\ North Carolina 27606-1499, USA \\ ${ }^{2}$ National Center for Mariculture, Israel Oceanographic \& Limnological Research, PO Box 1212, Eilat 88112, Israel \\ ${ }^{3}$ Center for Coastal Fisheries and Habitat Research, NOAA National Ocean Service, 101 Pivers Island Road, Beaufort, \\ North Carolina 28516-9722, USA
}

\begin{abstract}
Amyloodiniosis, caused by the dinoflagellate ectoparasite Amyloodinium ocellatum, is one of the most serious diseases affecting marine fish in warm and temperate waters. Current diagnostic methods rely entirely on the microscopic identification of parasites on the skin or gills of infested fish. However, subclinical infestations usually go undetected, while no method of detecting the free-swimming, infective (dinospore) stage has been devised. Targeting the parasite's ribosomal DNA region, we have developed a sensitive and specific PCR assay that can detect as little as a single cell from any of the 3 stages of the parasite's life cycle (trophont, tomont, dinospore). This assay performs equally well in a simple artificial seawater medium and in natural seawater containing a plankton community assemblage. The assay is also not inhibited by gill tissue. Sequence analysis of the internal transcribed spacer region of $5 \mathrm{~A}$. ocellatum isolates, obtained from fish in the Red Sea (Israel), eastern Mediterranean Sea (Israel), Adriatic Sea (Italy), Gulf of Mexico (Florida), and from an unknown origin, revealed insignificant variation, indicating that all isolates were the same species. However, 3 of these isolates propagated in cell culture varied in behavior and morphology, and these differences were consistent during at least $2 \mathrm{yr}$ in culture. Thus, our findings do not eliminate the possibility that different strains are in fact 'subspecies' or lower taxa, which may also differ in pathogenic and immunogenic characteristics, environmental tolerance, and other features.
\end{abstract}

KEY WORDS: Amyloodiniosis · rDNA probe $\cdot$ Epidemiology

\section{INTRODUCTION}

Amyloodinium ocellatum is an extremely prolific and devastating ectoparasitic dinoflagellate of fish in both marine and brackish water environments. Its life cycle is triphasic, consisting of a parasitic trophont, a reproductive tomont, and an infective motile dinospore stage. Most fish within the ecological range of this parasite are susceptible to infestation. Outbreaks in wild fish populations are probably rare, due to the low density of the parasite in an open environment. However, where conditions are conducive, rapid development of high parasite loads may lead to clinical disease and death. These conditions are more likely to occur in confinement and/or high fish densities such as those that occur in aquaculture. Reproduction is suspended at $15^{\circ} \mathrm{C}$ (Paperna 1984), which explains why epidemics occur only in tropical environments, or in temperate regions during warmer times of the year. Epidemics have been reported at salinities ranging from 3 to 50 psu (Lawler 1980, Paperna 1984, Kuperman \& Matey 1999, Kuperman et al. 2001). Although Amyloodinium is considered to be a monophyletic species, it has a worldwide distribution, and various isolates 
differ in temperature and/or salinity tolerance (Lawler 1980, Paperna 1984, Fielder \& Bardsley 1999, Kuperman et al. 2001), prompting some investigators to suggest that there may be more than a single Amyloodinium species (Landsberg et al. 1994).

Fish with amyloodiniosis often develop behavioral changes such as 'flashing' and rapid respiration. When skin infestations are heavy, parasites may produce a velvety sheen that can be seen using indirect illumination. Clinical diagnosis has been dependent on microscopic confirmation of the parasites on infested skin or gills. This involves skin or gill biopsy to find trophonts that are either attached or that dislodge as a consequence of sampling, rapidly turning into tomonts. Control is most successful when a diagnosis is made while the parasite load is still low. Since most drugs act only against the infective dinospore and are generally ineffective against the trophont or tomont, there is a significant delay in clinical improvement after initiation of therapy. Microscopic diagnosis is obviously more easily accomplished when parasites are numerous, in which case, however, the disease has often spread beyond control. Similarly, because a specific immune response is slow to develop (Cobb et al. 1998, Cecchini et al. 2001), antibody-based tests are not useful in detecting acute outbreaks. Thus, the aim of our investigation was to genetically compare several isolates of Amyloodinium ocellatum, and then develop a PCR assay based on unique, conserved DNA sequences that would detect dinospores in seawater and low levels of trophonts or tomonts in tissue, which may go undetected or misidentified by microscopic observation.

\section{MATERIALS AND METHODS}

Amyloodinium ocellatum isolates. Five isolates of $A$. ocellatum were used in this study. The DC-1 isolate originated from common clownfish A. ocellaris obtained from the commercial pet trade. This isolate was maintained in vitro on a fish gill cell line (G1B) in a minimal salt medium (IO2/ HBSS) for more than $16 \mathrm{yr}$ according to the method of Noga (1992). Similarly, parasites from striped bass Morone saxatilis farmed on the coast of the Gulf of Eilat, Israel (Red Sea isolate), and red drum Sciaenops ocellatus from brackish water ponds on the coast of the Gulf of Mexico, Florida, USA (Gulf of Mexico isolate), were placed into culture using the same method. Trophonts were also recovered from heavily infested, farmed European sea bass Dicentrarchus labrax from the Italian coast of the Adriatic Sea (Adriatic Sea isolate) and farmed sea bream Sparus aurata from the Mediterranean coast of Israel (eastern Mediterranean Sea isolate). The latter 2 isolates were immediately preserved in $70 \%$ ethanol after collection and prior to DNA extraction. The former 3 isolates were used both live and after ethanol preservation.

DNA extraction, PCR amplification, and sequencing of ribosomal DNA (rDNA). DNA was obtained from cell-cultured dinospores of the DC-1, Gulf of Mexico, and Red Sea isolates. Briefly, several thousand tomonts were harvested from $25 \mathrm{~cm}^{2}$ flasks of G1B cells that had been inoculated with 500 to 5000 dinospores. After 3 to $12 \mathrm{~d}$ at $25^{\circ} \mathrm{C}$, tomonts were harvested by aspirating the culture supernatant and transferring it to a $15 \mathrm{ml}$ conical centrifuge tube. After 10 to $15 \mathrm{~min}$, the tomonts settled to the bottom of the tube, separating them from remaining G1B cells. The overlying medium was aspirated off and the cells were gently washed with $\sim 12 \mathrm{ml}$ of IO2/HBSS. The settling and washing procedure was then repeated 2 more times to remove any remaining cellular debris.

Approximately 500 of the washed and settled tomonts were placed into each well of a 24 -well tissue culture plate containing $2.5 \mathrm{ml}$ of IO2/HBSS at $25^{\circ} \mathrm{C}$. Beginning at approximately $48 \mathrm{~h}$, dinospores emerged and were collected by placing a pipette tip at the edge of the well and slowly withdrawing the medium while leaving any developing tomonts in the bottom of the well. The remaining tomonts were then covered with the same volume of medium. Dinospores were harvested using the same procedure at $24 \mathrm{~h}$ intervals for an additional 2 or $3 \mathrm{~d}$. Dinospores collected in this manner were used for DNA extraction within $4 \mathrm{~h}$ of harvest or were preserved in $70 \%$ ethanol for later use.

For genomic DNA extraction from the DC-1, Gulf of Mexico, and Red Sea isolates, approximately 5000 dinospores were centrifuged in a $1.5 \mathrm{ml}$ conical tube at $14000 \times g$ for $5 \mathrm{~min}$. The supernatant was aspirated, and $1 \mathrm{ml}$ of IO2/HBSS was added to the pellet. The parasite pellet was not resuspended. The centrifugation and IO2/HBSS addition steps were then repeated 2 more times. The pellet was then macerated with a disposable pellet pestle (Kontes, Fisher Scientific). The DNA was extracted from the homogenate using the DNeasy Tissue Kit (Qiagen) according to the manufacturer's instructions.

Genomic DNA from the 2 ethanol-preserved isolates (Adriatic Sea isolate and eastern Mediterranean Sea isolate) was obtained by extracting the cells using the Mo Bio Soil Extraction Kit (Mo Bio Laboratories) according to the manufacturer's protocol.

For all 5 isolates, the rDNA complex region spanning from the start of the small subunit (SSU) rDNA through the first $\sim 50$ bp of the large subunit (LSU), and including the internal transcribed spacer 1 (ITS1), 5.8S, and ITS2 regions, was PCR-amplified using the following primer pair: Dino5'UF 5'-CAACCTGGTGATCCTG CCAGT-3' and ITSR 5'-TCCCTGTTCATTCGCCA TTAC-3'. The 
reaction mix contained $\sim 100 \mathrm{ng}$ of Amyloodinium ocellatum genomic DNA, 10X buffer, $2.5 \mathrm{U}$ Taq polymerase (Expand Long Template PCR system, Roche), $10 \mathrm{mM}$ of each dNTP, and $100 \mathrm{ng}$ of each primer in a final reaction volume of $50 \mu \mathrm{l}$. Amplifications were carried out in a Robocycler (Stratagene) using the following conditions: 2 min at $94^{\circ} \mathrm{C}$ followed by 35 cycles $\left(30 \mathrm{~s}\right.$ at $94^{\circ} \mathrm{C}$, $45 \mathrm{~s}$ at $60^{\circ} \mathrm{C}, 4 \mathrm{~min}$ at $68^{\circ} \mathrm{C}$ ), with a final extension of $5 \mathrm{~min}$ at $68^{\circ} \mathrm{C}$. Amplicons were cleaned using the QIAquick PCR purification kit (Qiagen), quantified spectrophotometrically, and sequenced on an ABI377 DNA sequencer using the Deoxy Terminator Cycle sequencing kit (Applied Biosystems). Sequencing was performed following the manufacturer's instructions and using approximately $10 \mathrm{ng}$ of DNA for each $100 \mathrm{bp}$ of template DNA and 25 pmol of primer. DNA templates were sequenced completely in both directions using the primers listed in Litaker et al. (1999, 2003). Completed sequences were submitted to GenBank: DC-1 (AF352359-AF352362, AF080096); Red Sea (DQ490268-DQ490271, DQ490257); Gulf of Mexico (DQ490259-DQ490260); Adriatic Sea (DQ490261-DQ490263, DQ490258); Mediterranean Sea (DQ490264-DQ490267, DQ490256).

SSU and ITS sequence variation among ribosomal copies from the same isolate and among the five Amyloodinium isolates. Multiple clones, representing different ribosomal copies, were sequenced from each of the 5 isolates. The aligned sequences were analyzed using a maximum likelihood Bayesian inference analysis as described by Litaker et al. $(2003,2005)$ to determine how similar the SSU and ITS copies were both within and among genomes.

Development of an Amyloodinium-specific PCR assay. Sequences determined in our study, as well as related dinoflagellate sequences accessed from GenBank, were aligned using the CLUSTAL-W algorithm (Thompson et al. 1994) included in the MacVector 7.0 software package (Oxford Molecular). These alignments allowed identification of unique primer sites for species-specific PCR assay development. The candidate primer sites selected for developing the Amyloodinium ocellatum-specific assay were AO18SF1 5'GACCTTGCCCGAGAGGG 3' and AO18SR1 5'GA AAGTGTGGTGAATCTTAAC $3^{\prime}$. These primers amplify a $248 \mathrm{bp}$ region located at the $3^{\prime}$ end of the SSU rDNA gene. PCR amplifications using this primer pair were optimized for the genomic A. ocellatum DNA. The reaction mix found to be optimal in this study utilized HotStartTaq (Qiagen), $100 \mathrm{ng}$ of genomic DNA, and $100 \mathrm{ng}$ of each primer in a final reaction volume of $50 \mu \mathrm{l}$. Amplifications were carried out in a Robocycler using the following conditions: $15 \mathrm{~min}$ at $94^{\circ} \mathrm{C}$, followed by 35 cycles $\left(1 \mathrm{~min}\right.$ at $94^{\circ} \mathrm{C}$, $1 \mathrm{~min}$ at $58^{\circ} \mathrm{C}, 1 \mathrm{~min}$ at $72^{\circ} \mathrm{C}$ ), and a final extension of 5 min at $72^{\circ} \mathrm{C}$.
Besides a search of existing GenBank sequences, the specificity of the Amyloodinium ocellatum oligonucleotide primers was tested using genomic DNA extracted from a panel of related dinoflagellate species in the National Oceanic and Atmospheric Administration (NOAA) culture collection (Table 1). Genomic DNA from these test species was obtained by filtering approximately $100 \mathrm{ml}$ of log phase culture of each species through a Nucleopore filter ( $3 \mu \mathrm{m}$ pore size) and then extracting the cells using the Mo Bio Soil Extraction Kit according to the manufacturer's protocol. Approximately $100 \mathrm{ng}$ of each extract were PCR amplified as described above.

Sensitivity and specificity of the assay. The minimum number of parasites that was detectable in the assay was determined by counting an Amyloodinium dinospore suspension in a hemacytometer and then serially diluting the dinospores in TE $(10 \mathrm{mM}$ Tris buffer + 1 mM EDTA, pH 8.0) to final concentrations of $250,100,50,10$, or 1 dinospore $\mathrm{ml}^{-1}$. Genomic DNA was then extracted from $1 \mathrm{ml}$ aliquots of each dilution using the Mo Bio Soil Extraction Kit. The final elution volume in the last step was kept constant at $50 \mu l$. The extracted genomic DNAs were then PCR-amplified using the A. ocellatum-specific primers as described above, except that $4 \mu \mathrm{l}$ of each extract were added rather than a fixed concentration of $100 \mathrm{ng}$. Each assay was performed in duplicate.

Because field samples are likely to contain numerous microorganisms besides Amyloodinium ocellatum, the sensitivity of the assay in the presence of a natural plankton assemblage was assessed. This was done by spiking a natural seawater sample with $A$. ocellatum dinospores (DC-1 isolate) to a final concentration of 1 dinospore $\mathrm{ml}^{-1}$. The seawater sample used for this experiment was 25 psu seawater collected near Beaufort, North Carolina, USA; it was pre-filtered through a $90 \mu \mathrm{m}$ mesh net to remove larger zooplankton grazers, but otherwise contained a naturally occurring plankton community. Ten $1 \mathrm{ml}$ aliquots of spiked seawater were extracted and amplified as described above for this experiment.

To confirm that the trophont and tomont stages could be detected, single trophonts or tomonts of the Red Sea isolate were tested in the PCR assay. Approximately $72 \mathrm{~h}$ after inoculating a G1B monolayer with dinospores, the culture, having numerous trophonts (attached to G1B cells) and tomonts (at least 2-cell stage), was fixed by adding $95 \%$ ethanol (2 parts ethanol:1 part medium). After $15 \mathrm{~min}$, the flask was gently agitated to detach the parasites, and $5 \mathrm{ml}$ were added to a watch glass. The watch glass was placed on an inverted microscope and a microliter pipette was used to remove single trophonts and tomonts from the watch glass. Individual parasites (5 trophonts and five 
Table 2. Response in the Amyloodinium ocellatum-specific PCR assay when testing either naturally infested gill tissue, a single parasite in artificial seawater, or uninfested gill tissue spiked with a single parasite. Ethanol-preserved gill samples were taken from fish showing clinical signs of amyloodiniosis. A small piece of gill tissue with parasites was extracted. Infestation of tissue samples ranged from mild to severe. Samples 1-3 were from European sea bass Dicentrarchus labrax, while samples 4-5 were from sea bream Sparus aurata. Each sample was from a unique case, except Samples 2 and 3, which were replications of the same sample at 2 different times. nd: not done

\begin{tabular}{|c|c|c|c|c|}
\hline \multirow[t]{2}{*}{ Sample no. } & \multirow{2}{*}{$\begin{array}{l}\text { Geographic } \\
\text { source }\end{array}$} & \multicolumn{3}{|c|}{ No. of PCR replicates/no. positive reactions } \\
\hline & & $\begin{array}{c}\text { Naturally } \\
\text { infested gill }\end{array}$ & $\begin{array}{l}\text { Single parasite } \\
\text { in seawater }{ }^{\mathrm{a}, \mathrm{b}}\end{array}$ & $\begin{array}{l}\text { Single parasite added } \\
\text { to uninfested gilla }{ }^{\mathrm{a}, \mathrm{c}}\end{array}$ \\
\hline 1 & Adriatic Sea & $5 / 5$ & $5 / 5$ & $5 / 5$ \\
\hline 2 & Eastern Mediterranean Sea & $5 / 5$ & $5 / 5$ & $5 / 5$ \\
\hline 3 & Eastern Mediterranean Sea & $5 / 5$ & $5 / 5$ & nd \\
\hline 4 & Red Sea & $5 / 5$ & $5 / 5$ & $5 / 5$ \\
\hline 5 & Red Sea & $5 / 5$ & $5 / 5$ & ND \\
\hline \multicolumn{5}{|c|}{$\begin{array}{l}\text { a Negative controls (without parasites) failed to amplify } \\
{ }^{\mathrm{b}} \mathrm{A} \text { single trophont or tomont was carefully dislodged from the infested gill tissue, added to artificial seawater medium } \\
\text { (IO2/HBSS), and then extracted } \\
\text { cSingle parasites (a single trophont or tomont) from the case was added to channel catfish gill tissue and then extracted }\end{array}$} \\
\hline
\end{tabular}

Pasteur pipette and then examined to ensure that it had not been lost during washing. After confirming via microscopy that a single parasite was still present after the last wash, each parasite was suspended in $50 \mu \mathrm{l}$ of TE and then extracted using the Mo Bio Soil Extraction Kit.

In the second experiment, uninfested gill tissue was spiked with a single parasite before extraction. This was done to determine whether there might be inhibitors in gill tissue that could prevent amplification at low parasite density. Single parasites were isolated from Cases 1, 2, and 4 (Table 2), and a single parasite was added to replicate $20 \mathrm{mg}$ aliquots of gill tissue of a freshwater fish, the channel catfish Ictalurus punctatus, which would never be exposed to Amyloodinium ocellatum. These spiked gill samples were then immediately extracted as described above for the naturally infested tissues.

Observations of live dinospores. Cell-cultured dinospores of the DC-1, Red Sea, and Gulf of Mexico isolates were observed using an inverted phase contrast microscope (Nikon Diaphot) at 40 to $250 \times$ magnification. Swimming behavior and morphology were noted for each isolate at least twice monthly over the course of 24 mo.

\section{RESULTS}

\section{Genetic relatedness of the five Amyloodinium ocellatum isolates}

The SSU rDNA sequences from all 5 geographic isolates, including DC-1, Adriatic Sea, eastern Mediterranean Sea, Red Sea, and Gulf of Mexico, were highly similar, their 18S rDNA genes having over 99.8\%
DNA sequence identity (GenBank accession numbers AF080096, DQ490256-DQ490258). The heterogeneity within the ITS region was higher, which is typical given that this region acts as a spacer region and not as a functional gene (Litaker et al. 2003). This heterogeneity was assessed by sequencing multiple copies of the ITS region from all 5 isolates. Approximately 30 polymorphisms were observed among copies of the ITS region in the DC-1, Adriatic Sea, eastern Mediterranean Sea, and Gulf of Mexico isolates, and 10 polymorphisms were present in the Red Sea isolate (GenBank accession numbers AF352359-AF352362, DQ490259-DQ490271). Whether fewer polymorphisms in the Red Sea isolate truly represent a lower rate of variation or instead were due to small sample size could not be determined from our data. A phylogenetic analysis of ITS copies from all 5 isolates showed relative low rates of divergence $(<0.04$ substitutions per site) between alleles and extensive overlap among alleles from the different isolates (Fig. 1). There were no obvious groupings indicative of subspecies differentiation.

\section{Validation of the PCR assay}

The Amyloodinium ocellatum PCR assay reproducibly amplified a 248 bp region located at the 3 ' end of the SSU rDNA gene. The assay could detect a single dinospore suspended in either artificial seawater (IO2/HBSS; Fig. 2A) or in natural seawater containing a natural plankton assemblage that might contain potential inhibitors of the PCR reaction (Fig. 2B). Extracting a single trophont or a single tomont of the cell-cultured Red Sea isolate also consistently yielded the 248 bp amplicon ( $\mathrm{N}=5$; data not shown). 


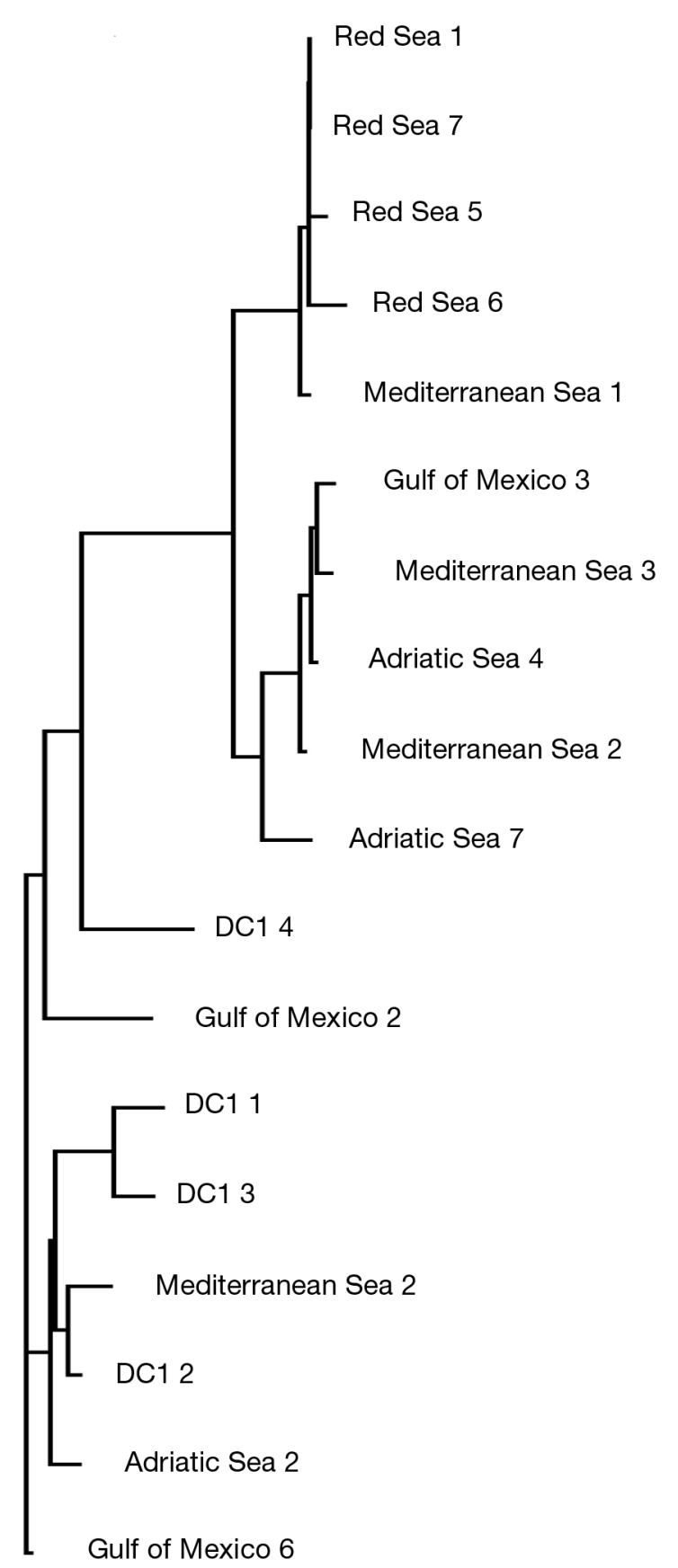

0.02 substitution per site

Fig. 1. Amyloodinium ocellatum. Relationship among the internal transcribed spacer (ITS) alleles from 5 isolates (Red Sea, Mediterranean Sea, Adriatic Sea, Gulf of Mexico, and DC-1, an isolate from the pet trade of unknown origin). There are multiple ITS copies within a cell; in the diagram, numbers following isolate designations from the various geographic regions indicate different ITS copies sequenced from that isolate. There are no obvious groupings indicative of subspecies differentiation. The ITS divergence between species is usually 0.08 substitutions per site or greater
PCR amplification of Amyloodinium ocellatum samples from natural epidemics, including either naturally infested gill samples having a mixture of trophonts and tomonts, a single tomont or trophont in seawater, or uninfested gill that was spiked with a single trophont or tomont, all consistently yielded the 248 bp A. ocellatum-specific amplicon. This was true for A. ocellatum isolates tested from all geographic sources. In addition, the A. ocellatum-specific PCR assay failed to amplify any of the related dinoflagellate species tested (Table 1).

\section{Simplified DNA preparation method}

Both 100 and 1000 boiled dinospores produced a strong $\sim 250 \mathrm{bp}$ PCR product. However, dinospores that were extracted using the DNeasy kit with a Proteinase $\mathrm{K}$ predigestion step produced only a moderate PCR band at 1000 dinospores and no band in the 100 dinospore amplifications (data not shown).

\section{Parasite behavior and morphology}

Dinospores of the DC-1 and Red Sea isolates exhibited more rapid swimming and less frequent pausing and turning compared to the Gulf of Mexico isolate. Red Sea isolate dinospores were more laterally compressed compared to the other 2 isolates. These behavioral and morphological differences were consistently observed over a 2 yr period, representing at least 100 complete life cycles for each isolate.

\section{DISCUSSION}

Means for treating amyloodiniosis are limited and include use of freshwater, formalin, and copper. The latter is the most commonly used drug, but at therapeutic dosages it only kills the dinospore stage. Amyloodiniosis outbreaks are typically diagnosed during acute episodes of the disease (Levy \& Noga 2006). At this stage, rates of morbidity and mortality are significantly high and the disease can be beyond control. Effective management lies in the ability to detect infestations at an early stage so that control measures can be adopted prior to the onset of clinical disease. For this purpose, microscopic examination of environmental water samples is impractical, as too few parasites are present in the water column, even during epidemics. Monitoring of fish populations using standard microscopic techniques by sampling selected individuals also lacks sensitivity unless infestation rates are high. In contrast, PCR is a highly sensitive and specific 


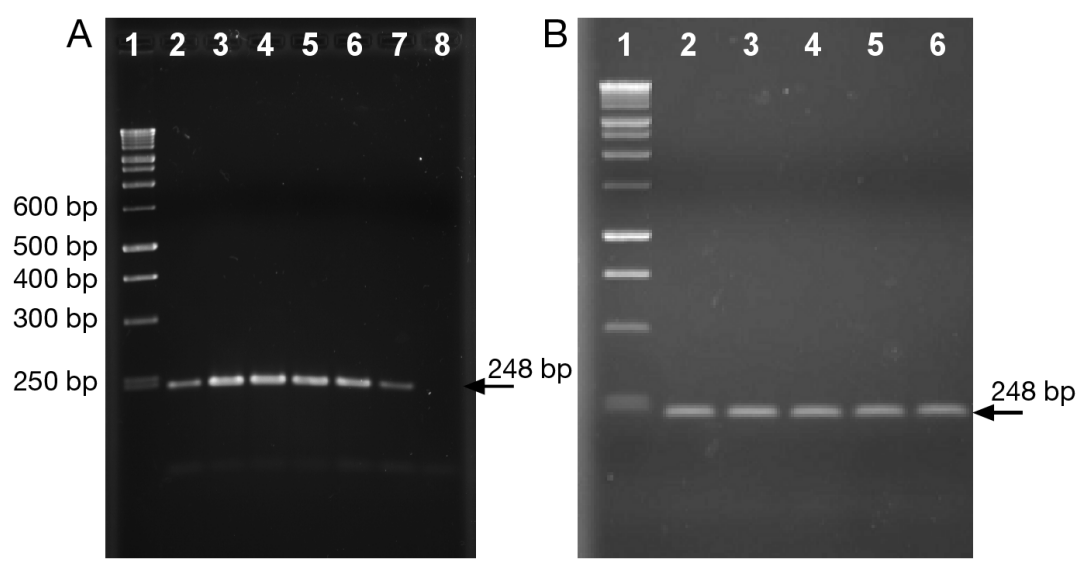

Fig. 2. Amyloodinium ocellatum. Sensitivity and specificity of the PCR assay. (A) Detection limit of the assay using dinospores diluted in artificial seawater medium (IO2/HBSS). Lane 1, 100 bp markers; Lane 2, positive control reaction using extracted genomic DNA; Lanes 3 to $7,250,100,50,10$, and 1 dinospore per PCR reaction, respectively. Lane 8, negative control (water) to confirm no cross-contamination of reagents. (B) Specificity of the assay for detecting a single dinospore in natural seawater having a plankton assemblage. Lane 1, $100 \mathrm{bp}$ mw markers. Lanes 2 to 6, 5 replicate assays of 1 dinospore $\mathrm{ml}^{-1}$ suspended in seawater containing a natural phytoplankton assemblage. Controls using either the natural plankton assemblage or no DNA (water) were negative. This experiment was replicated twice $(\mathrm{N}=10)$

method for detecting very small numbers of pathogens. Our PCR assay is suitable for all 3 stages of the parasite's life cycle: dinospore, trophont, and tomont. It is clearly capable of detecting low levels of infestation and could prove useful in a parasite monitoring program.

Our PCR assay might also be useful in gaining a better understanding of the dynamics of parasite prevalence in both cultured and wild populations. The host factors and environmental conditions that lead to amyloodiniosis outbreaks are poorly understood. Detection of low levels of infection is not necessarily followed by an outbreak. Being able to sensitively detect and monitor the presence of the parasite might provide insights into the mechanisms leading to an epidemic. These studies could be combined with measures of stress to determine if outbreaks occur as a result of host- or environment-related factors.

The SSU sequences varied from one another by $<0$ to $3 \mathrm{bp}$, and the ITS sequences by less than $\sim 0.03$ substitutions per site (Fig. 1). These levels of variation are within the typical level of variation for observed for other dinoflagellate species for each of these regions, indicating that all 5 Amyloodinium isolates belong to the same species (Litaker et al. 2003 unpubl. data). Landsberg et al. (1994) found that Amyloodinium dinospores obtained from fish in the Gulf of Mexico (Florida), the southwestern Atlantic (Florida), and a marine aquarium (unknown origin) all had the same Kofoidian plate tabulation pattern. The plate tabula- tion pattern is a highly reliable morphological feature for differentiating species of armored dinoflagellates; while the isolates were collected from within a small geographic range, these data also provide evidence for a single species of Amyloodinium.

Our genetic findings differ from those of another important protozoan ectoparasite genus, Ichthyobodo, which until recently was considered to constitute mainly a single species, I. necator. It now recognized that this taxon represents a multispecies complex containing at least 9 different species with varying host preferences (Todal et al. 2004, Callahan et al. 2005). Both SSU rDNA phylogenetic analysis and the ITS rDNA sequence data support this conclusion. Many of these species were isolated from multiple hosts, indicating that movement of infested fish from one region to another has a high potential for spreading exotic isolates. In one instance (Callahan et al. 2005), the same species was obtained from marine and freshwater fish, further suggesting that certain Ichthyobodo species may not be limited by salinity.

In contrast to Ichthyobodo, in which host preferences may be a factor driving evolutionary changes and these changes are reflected in heterogeneity in the ITS regions, the cosmopolitan nature of Amyloodinium, including its ability to parasitize invertebrates as well as fish (Colorni 1994), may serve to inhibit speciation. Indeed, the sequenced ITS regions of all A. ocellatum isolates were almost identical to one another. The possibility that additional species of Amyloodinium exist cannot be discounted at this time. Only with additional sequencing of other geographic isolates will we be able to determine more confidently whether A. ocellatum is indeed a monophyletic group. However, all isolates that we examined, which were all recovered from fish with amyloodiniosis, were A. ocellatum. Whether this is due to a natural pantropical distribution of this species or is the result of artificial distribution due to the movement of fish by humans cannot be resolved from our data. However, the widespread geographic distribution of this single species affecting virtually any teleost fish to which it is exposed is consistent with the perceived host range of this parasite (Lawler 1980).

While our genetic data strongly indicate that all isolates that we examined belong to a single species, cultured dinospores of the DC-1, Gulf of Mexico, and Red Sea isolates were easily distinguished by morphology and swimming behavior. Other investigators have noted differences in environmental tolerances of vari- 
ous Amyloodinium isolates, especially in regards to salinity (Lawler 1980, Paperna 1984, Fielder \& Bardsley 1999, Kuperman et al. 2001). These differences might be of practical significance if they reflect a variation in pathogenicity or immunogenicity. These differences suggest the possible existence of subspecies or lower taxa, which may also differ in pathogenic and immunogenic characteristics.

Acknowledgements. This work was supported by Research Grant No. US-3030-98 from the United States-Israel Binational Agricultural Research and Development (BARD) Fund and Grant \#NA46RG0087 from the National Sea Grant College Program, National Oceanic and Atmospheric Administration, to the North Carolina Sea Grant College Program. We are grateful to C. Lucangeli (Laboratorio di Medicina Veterinaria, Istituto Superiore di Sanità, Rome, Italy), M. Fioravanti (Faculty of Veterinary Medicine, University of Bologna, Italy), and S. Cecchini (University of Basilicata, Potenza, Italy), for their joint effort in providing the specimens from the Adriatic Sea.

\section{LITERATURE CITED}

Callahan HA, Litaker RW, Noga EJ (2005) Genetic relationships among members of the Ichthyobodo necator complex: implications for the management of aquaculture stocks. J Fish Dis 28:111-118

Cecchini S, Saroglia M, Terova G, Albanesi F (2001) Detection of antibody response against Amyloodinium ocellatum (Brown, 1931) in serum of naturally infected European sea bass by an enzyme-linked immunosorbent assay (ELISA). Bull Eur Assoc Fish Pathol 21:104-108

Cobb CS, Levy MG, Noga EJ (1998) Development of immunity by the tomato clownfish Amphiprion frenatus to the dinoflagellate parasite Amyloodinium ocellatum. J Aquat Anim Health 10:259-263

Colorni A (1994) Hyperparasitism of Amyloodinium ocellatum (Dinoflagellida: Oodinidae) on Neobenedenia melleni (Monogenea: Capsalidae). Dis Aquat Org 19:157-159

Fielder DS, Bardsley W (1999) A preliminary study on the effects of salinity on growth and survival of mulloway Argyrosomus japonicus larvae and juveniles. J World Aquac Soc 30:380-387

Editorial responsibility: Dieter Steinhagen, Hannover, Germany
Kuperman BI, Matey VE (1999) Massive infestation by Amyloodinium ocellatum (Dinoflagellida) of fish in a highly saline lake, Salton Sea, California, USA. Dis Aquat Org 39:65-73

Kuperman BI, Matey VE, Hurlbert SH (2001) Parasites of fish from the Salton Sea, California, U.S.A. Hydrobiologia 466: $195-208$

Landsberg JH, Steidinger KA, Blakesley BA, Zondervan RL (1994) Scanning electron microscope study of dinospores of Amyloodinium cf. ocellatum, a pathogenic dinoflagellate of marine fish, and comments on its relationship to the Peridinales. Dis Aquat Org 20:23-32

Lawler AR (1980) Studies on Amyloodinium ocellatum (Dinoflagellata) in Mississippi Sound: natural and experimental hosts. Gulf Res Rep 6:403-413

Litaker RW, Tester PA, Colorni A, Levy MG, Noga EJ (1999) The phylogenetic relationship of Pfiesteria piscicida, cryptoperidiniopsoid sp., Amyloodinium ocellatum and a Pfiesteria-like dinoflagellate to other dinoflagellates and apicomplexans. J Phycol 6:1379-1389

Litaker RW, Vandersea MW, Kibler SR, Reece KS and 6 others (2003) Identification of Pfiesteria piscicida (Dinophyceae) and Pfiesteria-like organisms using ITS-specific PCR assays. J Phycol 39:754-761

Litaker RW, Steidinger KA, Mason PL, Landsberg JH and 7 others (2005) The reclassification of Pfiesteria shumwayae: Pseudopfiesteria, gen. nov. J Phycol 41:643-651

Noga EJ (1992) Immune response to ectoparasitic protozoa: the infectivity assay. In: Stolen JS, Fletcher TC, Anderson DP, Kaattari SL, Rowley AF (eds) Techniques in fish immunology. SOS Publ, Fair Haven, NJ, p 167-176

Noga EJ, Levy MG (2006) Phylum Dinoflagellata. In: Woo PTK (ed) Fish diseases and disorders, Vol 1. Protozoan and metazoan infections, 2nd edn. CABI, Oxford, p 16-45

Paperna I (1984) Reproduction cycle and tolerance to temperature and salinity of Amyloodinium ocellatum (Brown, 1931) (Dinoflagellida). Ann Parasitol Hum Comp 59:7-30

Saldarriaga JF, McEwan ML, Fast NM, Taylor FJR, Keeling PJ (2003) Multiple protein phylogenies show that Oxyrrhis marina and Perkinsus marinus are early branches of the dinoflagellate lineage. Int J Syst Evol Microbiol 53:355-365

Thompson JD, Higgins DG, Gibson TJ (1994) Improving the sensitivity of progressive multiple sequence alignment through sequence weighting, position-specific gap penalties and weight matrix choice. Nucleic Acids Res 22: $4673-4680$

Todal JA, Karlsbakk E, Isaksen TE, Plarre H and 5 others (2004) Ichthyobodo necator (Kinetoplastida) - a complex of sibling species. Dis Aquat Org 58:9-16

Submitted: May 2, 2006; Accepted: September 20, 2006

Proofs received from author(s): December 20, 2006 